\title{
WestVirginiaUniversity
}

THE RESEARCH REPOSITORY @ WVU

Graduate Theses, Dissertations, and Problem Reports

2005

\section{Bioleaching and electrobioleaching of sulfide minerals}

\author{
Brian D. Conner \\ West Virginia University
}

Follow this and additional works at: https://researchrepository.wvu.edu/etd

\section{Recommended Citation}

Conner, Brian D., "Bioleaching and electrobioleaching of sulfide minerals" (2005). Graduate Theses, Dissertations, and Problem Reports. 1588.

https://researchrepository.wvu.edu/etd/1588

This Thesis is protected by copyright and/or related rights. It has been brought to you by the The Research Repository @ WVU with permission from the rights-holder(s). You are free to use this Thesis in any way that is permitted by the copyright and related rights legislation that applies to your use. For other uses you must obtain permission from the rights-holder(s) directly, unless additional rights are indicated by a Creative Commons license in the record and/ or on the work itself. This Thesis has been accepted for inclusion in WVU Graduate Theses, Dissertations, and Problem Reports collection by an authorized administrator of The Research Repository @ WVU. For more information, please contact researchrepository@mail.wvu.edu. 


\title{
BIOLEACHING AND ELECTROBIOLEACHING OF SULFIDE MINERALS
}

\author{
by \\ Brian D. Conner \\ Thesis submitted to the College of Engineering \\ and Mineral Resources \\ at West Virginia University \\ in partial fulfillment of the requirements \\ for the degree of \\ Master of Science in \\ Chemical Engineering
}

Approved by

Eung H. Cho, Ph.D., Committee Chairperson Joseph A. Shaeiwitz, Ph.D.

Ray Y.K. Yang, Ph.D.

Department of Chemical Engineering

Morgantown, West Virginia

2005

Keywords: Bioleaching, Sulfide Minerals, A. ferrooxidans, Sphalerite, Pyrite, Chalcopyrite

Copyright 2005 Brian D. Conner 


\section{ABSTRACT \\ BIOLEACHING AND ELECTROBIOLEACHING OF SULFIDE MINERALS}

by Brian D. Conner

Three sulfide minerals, chalcopyrite, sphalerite, and pyrite, were leached using a bioleaching mode and an electrobioleaching mode. The former mode was used to leach the minerals with the bacterium $A$. ferrooxidans in a bioreactor. In the latter mode, the leaching of the minerals was performed in a combination of a bioreactor and an electrochemical cell. In this set-up, a solution was drained from the bioreactor by gravity to the cathode compartment where the $\mathrm{Fe}(\mathrm{III})$ content was reduced to $\mathrm{Fe}(\mathrm{II})$ before the solution was pumped back to the bioreactor. The idea is that an increase in $\mathrm{Fe}(\mathrm{II})$ concentration, which is a nutrient of the bacteria, by electrochemical reduction of $\mathrm{Fe}(\mathrm{III})$ would increase the bacterial population and in turn would accelerate the leaching of the mineral.

It has been found that the electrobioleaching of chalcopyrite is superior to the bioleaching with respect to the fact that leaching conversion is higher and a high level of $\mathrm{Fe}(\mathrm{II})$ can be maintained. However, the electrobioleaching of sphalerite does not show an improvement over bioleaching. The electrobioleaching of pyrite is similar to that of chalcopyrite, and this has potential to be used in applications such as coal desulfurization and pretreatment of refractory gold ore in heap leaching. 


\section{DEDICATION}

The author wishes to dedicate this work to Grandpa Sam for always believing in me. 


\section{ACKNOWLEDGMENTS}

The author wishes to express his gratitude and appreciation to his adviser, Dr. Eung H. Cho, for all of his hard work, time, effort, and advice throughout this project

To Dr. Ray Y.K. Yang, for his time and assistance with this project.

To Dr. Joseph Shaeiwitz, for his time and assistance with this project.

To Mr. Jim Hall, for his assistance with the fabrication of the experimental apparatus.

To Dr. Russell MacDonald, at lonics Inc., for the donation of anionic membranes.

To Dr. Batric Pesic, Professor at the University of Idaho, for his advice on electrochemical applications.

To the National Energy Technology Laboratory/U.S. Department of Energy for financial support with a grant (No. CR-429168) through the CAST program which made this research possible.

To his family for a lifetime of love and support.

To Lesley McPherson and Bradley Powers for being the best cheerleaders a man could hope for. 


\section{TABLE OF CONTENTS}

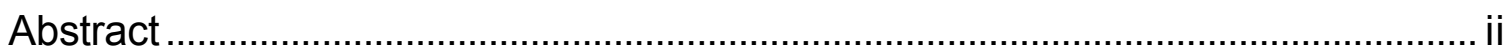

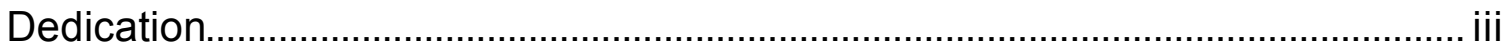

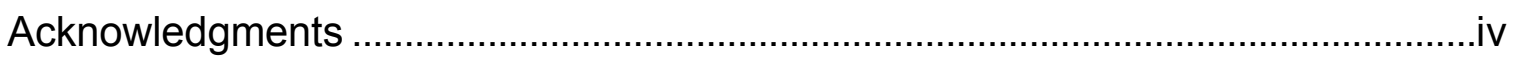

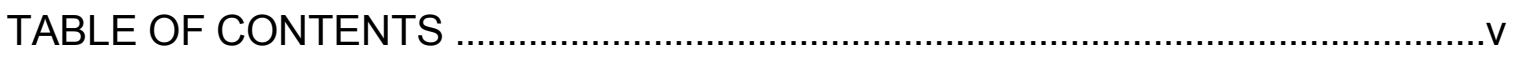

LIST OF FIGURES................................................................................................

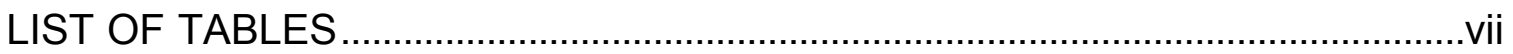

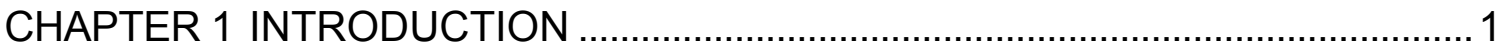

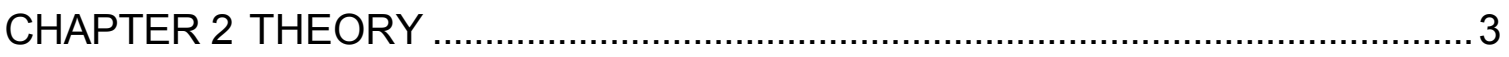

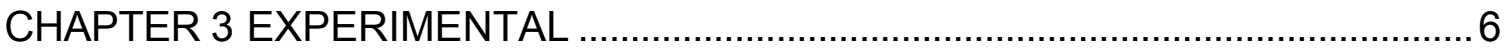

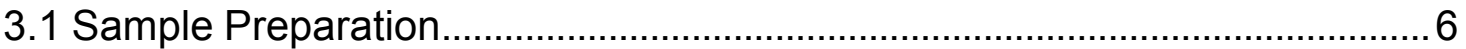

3.2 Culture History and Procedure ..................................................................... 7

3.2.1 Culture Origination .........................................................................

3.2.2 First \& Second Subcultures ........................................................... 8

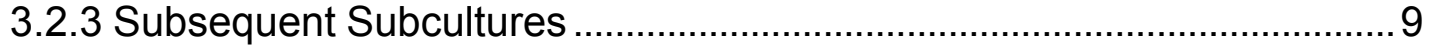

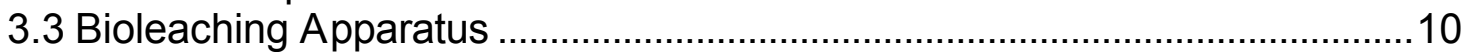

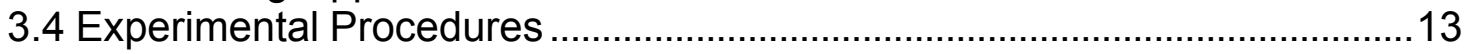

CHAPTER 4 RESULTS AND DISCUSSION …….............................................17

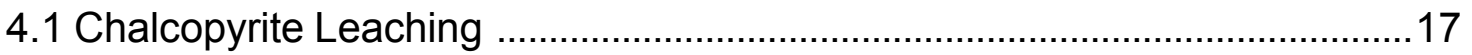

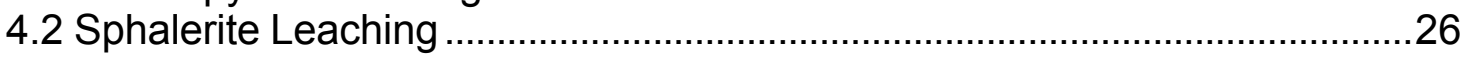

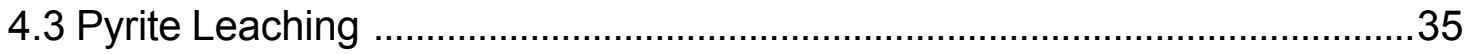

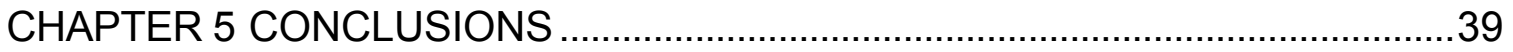

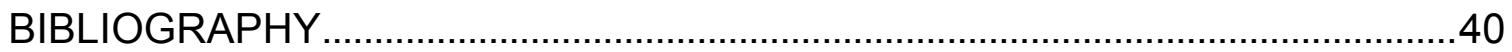




\section{LIST OF FIGURES}

Figure 1. Schematic of experimental set-up for electrobioleaching mode...........11

Figure 2. Leaching conversion of chalcopyrite in bioleaching and electrobioleaching modes.

Figure 3. Concentrations of $\mathrm{Fe}(\mathrm{II}), \mathrm{Fe}(\mathrm{III})$, and $\mathrm{Fe}$ (total) during chalcopyrite leaching in bioleaching mode.

Figure 4. Concentrations of $\mathrm{Fe}(\mathrm{II}), \mathrm{Fe}(\mathrm{III})$, and $\mathrm{Fe}$ (total) during chalcopyrite leaching in electrobioleaching mode.

Figure 5. Precipitation of soluble iron during chalcopyrite leaching in bioleaching and electrobioleaching modes.

Figure 6. Leaching of chalcopyrite and sphalerite in 0.053 molar ferric solution. 24

Figure 7. Leaching conversion of sphalerite in bioleaching and electrobioleaching modes

Figure 8. Concentrations of $\mathrm{Fe}(\mathrm{II}), \mathrm{Fe}(\mathrm{III})$, and $\mathrm{Fe}$ (total) during sphalerite leaching in bioleaching mode. 28

Figure 9. Concentrations of $\mathrm{Fe}(\mathrm{II}), \mathrm{Fe}(\mathrm{III})$, and $\mathrm{Fe}$ (total) during sphalerite leaching in electrobioleaching mode.

Figure 10. Precipitation of soluble iron during sphalerite leaching in bioleaching and electrobioleaching modes.

Figure 11. Concentrations of $\mathrm{Fe}(\mathrm{II}), \mathrm{Fe}(\mathrm{III})$, and $\mathrm{Fe}($ total) during pyrite leaching in bioleaching mode.

Figure 12. Concentrations of $\mathrm{Fe}(\mathrm{II}), \mathrm{Fe}(\mathrm{III})$, and $\mathrm{Fe}($ total) during pyrite leaching in electrobioleaching mode. 


\section{LIST OF TABLES}

Table 1. Chemical Analysis Results for Mineral Samples ...................................... 7 


\section{CHAPTER 1 \\ INTRODUCTION}

Bioleaching of sulfide minerals using the bacteria Acidithiobacillus ferrooxidans has been recognized as a promising method as it applies to leaching of low-grade, mixed-sulfide ore in a heap leaching or a dump leaching environment. Numerous papers have been published during the 1980 s and 1990s, many of them at technical conferences, providing a wealth of background information on this subject. The mixed sulfide ore commonly contains sulfide minerals of iron, copper, and zinc. This bioleaching method presents many potential advantages over conventional pyrometallurgical techniques because it can be applied to all ore grades and to waste materials produced by conventional ore dressing. Also, it is an environmentally sound technique as it does not give rise to atmospheric pollution and has a low energy requirement. However, a general problem with the bioleaching method is that the leaching rate is so low that it takes a long period of time (1 $-2 \mathrm{yrs})$ to complete the heap or dump leaching operation. This slow rate has been the major restriction to wider commercialization of this biotechnology.

According to statistics published in the early 1980 s $^{(1)}$, about $18 \%$ of copper production in the United States is estimated to derive from in-situ, dump and heap leaching. Since the amount of low-grade ore of sulfide minerals is continually increasing, the necessity for application of this bioleaching technology has increased accordingly. 
The leaching rate can be enhanced by applying direct current potentials to the bioleaching system. ${ }^{(2)}$ The sulfide mineral is anodically polarized and is thus dissolved in the anodic compartment of an electrochemical cell. It was found ${ }^{(2)}$ that the leaching conversion of sphalerite or pyrite increased by $3-4$ times, in an 80 day leaching period, by application of anodic potential, which was characteristic of each mineral. It was also found that the leaching conversion of the minerals was further increased upon additional application of $A$. ferrooxidans.

Bacteria leaching can be enhanced by increasing bacterial population. $A$. ferrooxidans, the bacteria most widely used in bioleaching of sulfide minerals, was grown in an electrolytic bioreactor containing ferrous medium. ${ }^{(3)}$ Passage of current through the medium reduced the bacterially generated ferric iron to ferrous iron, increased the cell concentration by 3.7 times and also increased the ferrous oxidation rate by 1.5 times at $29^{\circ} \mathrm{C}$, compared with conventional cultivation techniques. ${ }^{(3)}$ It was found from a similar study ${ }^{(4)}$ that the bacterial growth rate increased at more negative potential in the range from 0 to -0.6 volts versus the glass reference electrode.

The present study is to adopt this mode of process in which $A$. ferrooxidans population is increased electrolytically or by reducing ferric to ferrous cathodically, and therefore enhancing the leaching of sulfide minerals. The objective of this project is to explore this new system as applied to bioleaching the sulfide minerals and particularly to determine its adaptability on each of sulfide minerals: chalcopyrite, sphalerite, and pyrite. 


\section{CHAPTER 2 \\ THEORY}

When sulfide minerals are leached in a bacteria-cultured solution with $A$. ferrooxidans, there are three categories of reactions that are closely related in determining their leaching rates. The mechanisms of these categories of the reactions are well reviewed in the literature. ${ }^{(5)}$ The first category is oxidation reactions of ferrous ion and elemental sulfur. A. ferrooxidans needs these reactions to grow and also catalyzes them. The bacteria grow in the presence of ferrous ion and/or elemental sulfur (nutrients) under acidic $(\mathrm{pH}<3.0)$ conditions. The reactions are:

$$
\begin{aligned}
& 4 \mathrm{Fe}^{2+}+\mathrm{O}_{2}+4 \mathrm{H}^{+}=4 \mathrm{Fe}^{3+}+2 \mathrm{H}_{2} \mathrm{O} \\
& 2 \mathrm{~S}+3 \mathrm{O}_{2}+2 \mathrm{H}_{2} \mathrm{O}=2 \mathrm{H}_{2} \mathrm{SO}_{4}
\end{aligned}
$$

It is noteworthy that reaction 1 is inhibited by the presence of some minerals. It was reported $^{(6)}$ that the presence of pyrite and coal inhibited the bacterial iron oxidation (reaction 1) to a great extent. Similar phenomena were observed with sphalerite. ${ }^{(7)}$ This inhibition seems to have much influence on the leaching mechanisms in the present study.

The second category is the indirect leaching reactions, which are the leaching reactions of sulfide minerals with ferric ions that are produced by the bacterial catalysis (reaction 1). The indirect reactions are: 


$$
\begin{aligned}
& \mathrm{FeS}_{2}+2 \mathrm{Fe}^{3+}=3 \mathrm{Fe}^{2+}+2 \mathrm{~S} \\
& \mathrm{CuFeS}_{2}+4 \mathrm{Fe}^{3+}=\mathrm{Cu}^{2+}+5 \mathrm{Fe}^{2+}+2 \mathrm{~S} \\
& \mathrm{ZnS}+2 \mathrm{Fe}^{3+}=\mathrm{Zn}^{2+}+2 \mathrm{Fe}^{2+}+\mathrm{S}
\end{aligned}
$$

The third category is the direct leaching reactions. These are the leaching reactions of sulfide minerals which are catalyzed by the bacteria. The direct reactions are:

$$
\begin{aligned}
& \mathrm{FeS}_{2}+15 / 4 \mathrm{O}_{2}+0.5 \mathrm{H}_{2} \mathrm{O}=\mathrm{Fe}^{3+}+2 \mathrm{SO}_{4}{ }^{2-}+\mathrm{H}^{+} \\
& \mathrm{CuFeS}_{2}+4.25 \mathrm{O}_{2}+\mathrm{H}^{+}=\mathrm{Cu}^{2+}+\mathrm{Fe}^{3+}+2 \mathrm{SO}_{4}{ }^{2-}+0.5 \mathrm{H}_{2} \mathrm{O} \\
& \mathrm{ZnS}+2 \mathrm{O}_{2}=\mathrm{ZnSO}_{4}
\end{aligned}
$$

Contribution of each category to the leaching rate varies from mineral to mineral. It is reported ${ }^{(5)}$ that sphalerite is mainly oxidized by the indirect leaching mechanism while chalcopyrite and pyrite are mainly oxidized by the direct leaching mechanism. It is expected that the different leaching behaviors of the two types of sulfide minerals may reveal different responses in the present study.

There is an additional factor that must be considered in understanding the leaching mechanisms in the present research. The leaching is limited by the presence of a diffusion barrier that is produced during the leaching reaction. As can be seen from reactions 3 through 5 , elemental sulfur is formed. The sulfur layer sometimes becomes a protective layer that limits the diffusion rate. It was reported $^{(8)}$ that the sulfur layer formed during the leaching of chalcopyrite with 
ferric sulfate became a complete protective layer with no crack and that further leaching should be carried on by a solid state diffusion mechanism through the sulfur layer. In the case of sphalerite leaching, a different mechanism is envisioned. It was reported ${ }^{(9)}$ that in the initial stages of sphalerite leaching $(\sim 13$ $-16 \%$ of leaching conversion), the leaching rate followed the shrinking core model. This suggested that the sulfur layer did not act as a protective layer; however, leaching beyond this initial state fit a model in which the rate is controlled by diffusion through the sulfur layer, suggesting that the sulfur layer does act like a protective layer. These mechanisms may impact the leaching behaviors of the sulfide minerals in the present study. 


\section{CHAPTER 3 \\ EXPERIMENTAL}

\subsection{Sample Preparation}

Lump samples $(5-10 \mathrm{~cm})$ of sphalerite $(\mathrm{ZnS})$, pyrite $\left(\mathrm{FeS}_{2}\right)$, and chalcopyrite $\left(\mathrm{CuFeS}_{2}\right)$, were obtained from Ward's Mineral (Rochester, NY). The samples were crushed by a jaw crusher to about $1 \mathrm{~cm}$ in size, manually sorted to remove conspicuous low-grade particles, crushed again by a roll crusher, and screened to produce a $150-200$ mesh ( $75-100$ microns) size fraction. This fraction was further treated to remove fines by decantation. The produced fraction of particles was slurried with about $500 \mathrm{~mL}$ of water in a one-liter beaker. The slurry was agitated by a swirling motion. When the agitation was stopped, the larger particles were allowed to settle, and the suspended fines were decanted. This procedure was repeated until only small amounts of fines could be seen in the agitated liquid. This fraction was air dried and used for leaching experiments.

Chemical analyses were conducted to determine the purity of each of the minerals. A one-gram sample was taken from each prepared size fraction, dissolved in boiling aqua regia, and filtered. The filtrate was properly diluted and analyzed for metal concentrations with an atomic absorption spectrophotometer. The metal concentrations were converted to purity of each mineral. Also, the percent of impurities were surmised from the metal concentrations by assuming that all the metals exist as metal sulfides. The results are summarized in Table 1. 
Table 1. Chemical Analysis Results for Mineral Samples

\begin{tabular}{|c|c|c|c|c|c|}
\hline \multirow{2}{*}{ Mineral } & Purity (\%) & sphalerite & chalcopyrite & pyrite & acid-insoluble \\
\cline { 3 - 6 } & & & 0.13 & 0.53 & 13.32 \\
\hline Sphalerite & 86.02 & - & - & 7.02 & 10.81 \\
\hline Chalcopyrite & 78.7 & 3.47 & 0.09 & - & 4.22 \\
\hline Pyrite & 95.53 & 0.16 & & -40 & \\
\hline
\end{tabular}

\subsection{Culture History and Procedure}

\subsubsection{Culture Origination}

A test tube containing a culture of the organism Acidithiobacillus ferrooxidans (ATCC 13598) was received and its initial propagation was as follows:

1. The contents of the test tube $(\sim 15 \mathrm{~mL})$ were divided equally amongst 3 $125 \mathrm{~mL}$ Erlenmeyer flasks.

2. A sterilized medium solution was filtered and added to each flask in a 5:1 ratio, resulting in each flask containing $\sim 30 \mathrm{~mL}$.

3. The flasks were sealed with sterile cotton.

4. The flasks were then transferred to an incubator where they were maintained at $26^{\circ} \mathrm{C}$ and shook at $250 \mathrm{rpm}$ in a random-orbit shaker.

All glassware used was dry sterilized at a temperature $160-180^{\circ} \mathrm{C}$ for at least 45 minutes. The filtering apparatus, for the medium solution, was a Nalgene Model $300-4000$, and the filter paper was Millipore TCMF (pore size $=0.22 \mu \mathrm{m} \&$ diameter $=47 \mathrm{~mm}$ ). The filtering apparatus and filter paper were steam sterilized and dried prior to use under the following cycle: sterilization at $120^{\circ} \mathrm{C}$ for $20 \mathrm{~min}$ 
and drying at $160^{\circ} \mathrm{C}$ for 30 minutes. All work took place in a laminar flow hood, which was cleaned with $70 \%$ ethanol and allowed to equilibrate prior to use.

A medium solution was prepared with part $A$ and part $B$.

Part A:

\begin{tabular}{|l|l|}
\hline $0.8 \mathrm{~g}$ ammonium sulfate & $\left(\mathrm{NH}_{4}\right)_{2} \mathrm{SO}_{4}$ \\
\hline $2.0 \mathrm{~g}$ magnesium sulfate heptahydrate & $\mathrm{MgSO}_{4} \cdot 7 \mathrm{H}_{2} \mathrm{O}$ \\
\hline $0.4 \mathrm{~g}$ potassium phosphate dibasic & $\mathrm{K}_{2} \mathrm{HPO}_{4}$ \\
\hline $5.0 \mathrm{~mL}$ ATCC Trace Mineral Supplement & $\mathrm{ATCC} \#$ MD-TMS \\
\hline $1.0 \mathrm{~N}$ sulfuric acid & $\mathrm{H}_{2} \mathrm{SO}_{4}$ \\
\hline
\end{tabular}

All ingredients were dissolved in $\sim 600 \mathrm{~mL}$ of deionized water and the $\mathrm{pH}$ was adjusted to 2.3 using the sulfuric acid.

Part B:

Twenty grams of ferrous sulfate 7 -hydrate $\left(\mathrm{FeSO}_{4} \cdot 7 \mathrm{H}_{2} \mathrm{O}\right)$ was dissolved in 200 $\mathrm{mL}$ of deionized water.

Finally, parts A and B were combined and the volume was brought up to $1.0 \mathrm{~L}$ using deionized water.

\subsubsection{First \& Second Subcultures}

1. Two of the three initial $125 \mathrm{~mL}$ flasks were selected for subculture. The contents (by volume) of each was determined and then equally divided in half.

2. The four portions were each then transferred to their own sterile $500 \mathrm{~mL}$ flask.

3. Filtered medium was added to each of the $4500-\mathrm{mL}$ flasks in a ratio of $5: 1$.

4. Each flask was sealed with sterile cotton and returned to the incubator $\left(26^{\circ} \mathrm{C}\right.$ and $\left.250 \mathrm{rpm}\right)$.

5. After 7 days, one of the four initial $500-\mathrm{mL}$ flasks was chosen and its volume was determined. 
6. Portions of equal size were then removed from this flask and transferred to new sterile $500-\mathrm{mL}$ flasks, so that the result was 4 flasks of equal volume. The original flask was labeled $\mathrm{P}$ (for parent) and the other three were labeled $\mathrm{C} 1, \mathrm{C} 2$, and $\mathrm{C} 3$.

7. Medium solution was then added to each flask to bring the total volumes to the levels as follows:

\begin{tabular}{|l|l|}
\hline$P(100)$ & $100 \mathrm{~mL}$ \\
\hline$C 1(150)$ & $150 \mathrm{~mL}$ \\
\hline$C 2(200)$ & $200 \mathrm{~mL}$ \\
\hline$C 3(250)$ & $250 \mathrm{~mL}$ \\
\hline
\end{tabular}

8. The flasks were then sealed with sterile cotton and returned to the incubator.

\subsubsection{Subsequent Subcultures}

To ensure the viability of the culture, the following procedure was used over the next few weeks:

1. From the flask to be cultured, $10 \mathrm{~mL}$ was removed and transferred to a fresh flask, resulting in a pair of flasks, with the second being the child of the first.

2. The volume of each was brought up to the initial volume of the parent and they were labeled. For example, the C1(100) flask became C1(100)-1 and $\mathrm{C} 1(100)-1 \mathrm{~s}$.

3. The flasks were then sealed with sterile cotton and returned to the incubator.

Ultimately, the total volume was standardized to $250 \mathrm{~mL}$, and a schedule of 14 days between subculture was adopted. After the viability of the culture was ensured, the culture procedure was changed slightly and accomplished as follows: 
1. From the flask to be cultured, $210-\mathrm{mL}$ portions were removed and transferred to fresh flasks. The volume was brought up to $250 \mathrm{~mL}$ using filtered medium and the labeling system was as follows: flask C2-4s became $\mathrm{C} 2-5 \mathrm{~s} 1$ and $\mathrm{C} 2-5 \mathrm{~s} 2$.

2. The flasks were then sealed with gas-permeable stoppers and returned to the incubator.

\subsection{Bioleaching Apparatus}

The bioreactor used in this study was fabricated of $4.8 \mathrm{~mm}$ thick, clear acrylic sheets. The base was 4 inches square and designed to hold 1 liter with sufficient head space. The top was left open to allow access for the stirrer and air bubbler. The solution was stirred with an overhead stirrer with an rpm setting high enough to ensure a well mixed environment. The impeller was coated with a vinyl-ester resin (Dow Derakane 411-350) to prevent interference with the reaction. To ensure that ample oxygen was available, dry-grade, compressed air was bubbled into the solution at a rate of approximately $7.1 \mathrm{~mL} / \mathrm{min}$. The solution was comprised of about $250 \mathrm{~mL}$ of a bacterial culture (7 days old) solution and $750 \mathrm{~mL}$ of $A$. ferrooxidans culture medium which contained $15 \mathrm{~g}$ of $\mathrm{FeSO}_{4} \cdot 7 \mathrm{H}_{2} \mathrm{O}$, $10 \mathrm{~mL}$ of trace mineral solution (ATCC Catalog MD-TMS), and was adjusted to $\mathrm{pH} 1.5$ using $1.0 \mathrm{~N}$ sulfuric acid. Then, $20 \mathrm{~g}$ of the mineral (pyrite, chalcopyrite, or sphalerite) was added to initiate the bioleaching reaction.

The electrobioleaching apparatus was more complicated. The apparatus consisted of a bioreactor and an electrochemical cell, as shown in Figure 1. The bioreactor was identical to the one mentioned previously except for a tap hole (23 $\mathrm{mm}$ diameter) drilled on one of the side panels. The tap hole was used to allow 


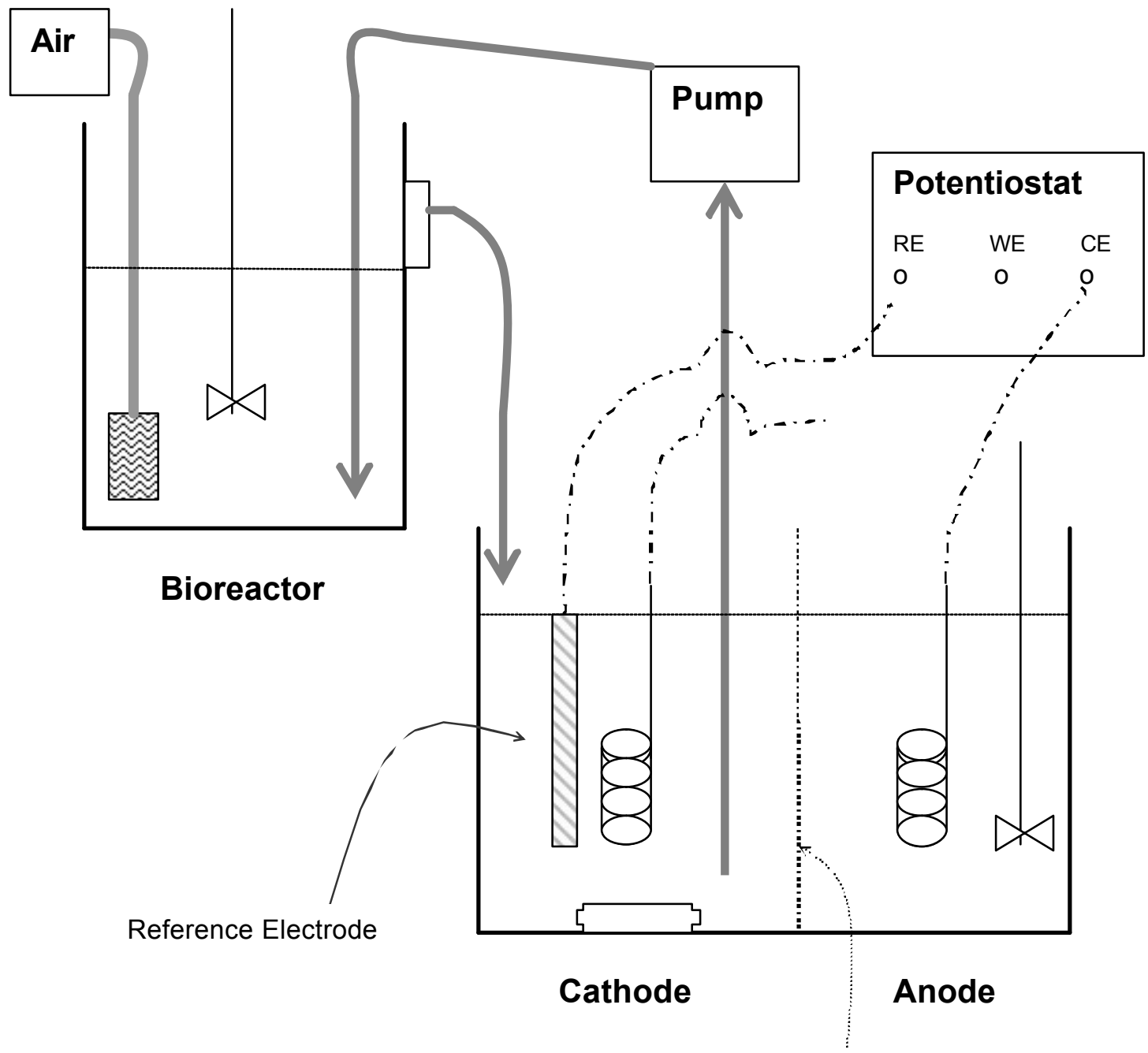

Anionic Membrane

Figure 1. Schematic of experimental set-up for electrobioleaching mode. 
the solution to flow back to the cathode compartment of the cell by gravity. The position of the tap hole was made so that the bottom of the hole coincided with the 1 liter mark in the reactor. The operation of the bioreactor in the electrobioleaching mode was basically the same as for the bioleaching mode outlined previously.

The electrochemical cell was also fabricated of $4.8 \mathrm{~mm}$ thick, clear acrylic sheets. The overall dimensions were $20 \mathrm{~cm}$ long, $10 \mathrm{~cm}$ wide, and $15 \mathrm{~cm}$ high. The cell was fabricated in two halves, with a flange on the open end of each half. A membrane along with two rubber gaskets were sandwiched between the two halves. The halves were then bolted together with fiberglass nuts and bolts. This clam-shell design allowed easy access to the membrane and the gaskets. The membrane (Ionics AR204-SZRA-412) was an anionic-exchange membrane designed to allow the passing of anions, but not cations. It was chosen to prevent ferric and ferrous ions from leaving the cathode compartment. The catholyte was stirred using a magnetic spin bar, while the anolyte was stirred using an overhead impeller, which has been coated with a vinyl-ester resin (Dow Derakane 411-350) to prevent interference.

Solution was pumped from the bottom of the cathode compartment to the bottom of the bioreactor using a peristaltic pump at a rate of approximately 1.55 $\mathrm{mL} / \mathrm{sec}$. Then the liquid level in the bioreactor rose, which caused the solution to be drained via gravity. When the experiment was started, the cathode contained 1 liter of $0.045 \mathrm{M}$ ferric sulfate solution adjusted to $\mathrm{pH} 1.5$ using $1 \mathrm{~N}$ sulfuric 
acid. The anode contained 1 liter of $0.2 \mathrm{M}$ sodium chloride solution at natural $\mathrm{pH}$. The current required to reduce the ferric iron in the cathode was supplied by a Perkin-Elmer Model 283 Potentiostat/Galvanostat. The working and counter electrodes were made of platinum -iridium ( $90 \%$ platinum, $10 \%$ iridium) mesh gauze, while the reference electrode was a saturated calomel electrode.

\subsection{Experimental Procedures}

The beginning of an experiment for the bioleaching mode was marked by the addition of mineral sample to the bioreactor. Twenty grams of the mineral sample was added to a mixture of $250 \mathrm{~mL}$ of subculture solution and $750 \mathrm{~mL}$ of 0.072 molar ferrous ion solution whose $\mathrm{pH}$ had been adjusted to 1.5 using $1.0 \mathrm{~N}$ sulfuric acid. The experiment was initiated when the reactor contents were agitated by an overhead stirrer. Air was blown into the reactor through a diffuser at a rate of $7.1 \mathrm{~mL} / \mathrm{min}$. On the third (or fourth) day and every 3 or 4 days thereafter, liquid samples were withdrawn from the bioreactor, filtered and analyzed for ferrous iron, total iron and zinc or copper. Five milliliters was pipetted for each ferrous and total iron analysis, $10 \mathrm{~mL}$ for copper, and $1 \mathrm{~mL}$ for zinc analysis. Fifteen minutes prior to sampling, the speed of the overheard stirrer was slowed. This was done to allow the solid mineral to settle out of solution, which in turn, kept it from being removed from the reactor.

Figure 1 shows a schematic of the experimental set-up for the electrobioleaching mode. The experiment for this mode was initiated and conducted the same way as the bioleaching mode for the first seven days. On 
the seventh day, one liter of each, catholyte and anolyte, was prepared and charged to their respective compartments. The catholyte was $0.045 \mathrm{M}$ ferric sulfate solution at $\mathrm{pH} 1.5$. The anolyte was $0.2 \mathrm{M}$ sodium chloride solution at natural $\mathrm{pH}$. Ferric sulfate was chosen for the catholyte because the ferrous ion in solution would eventually be converted to ferric ion by bacterial catalysis and this situation could be simulated from the beginning.

When the catholyte and anolyte were charged to their compartments, the catholyte and the bioreactor solution were circulated for two hours. This circulation was needed to homogenize the two solutions. At the end of two hours liquid samples were withdrawn from the bioreactor and analyzed for ferrous iron, total iron, and zinc or copper. At this point, the potentiostat was turned on and reduction was begun at the cathode. Current was applied for 4 to 5 hours. At the end of the reduction period, another sample was taken from the bioreactor and analyzed for ferrous iron. By knowing the change in ferrous iron concentration and the coulombs supplied, current efficiency was determined. After this sampling, the circulation and reduction were stopped. The reduction was conducted at a current ranging from 40 to $100 \mathrm{~mA}$ in potentiostatic (constant voltage) mode, during which the potential was manually adjusted. The potentials were varied from 0.2 to $0.05 \mathrm{~V}$ for chalcopyrite and pyrite and 0.2 to $-0.078 \mathrm{~V}$ for sphalerite, all against the saturated calomel electrode.

The electrochemical reduction was conducted whenever ferric concentration was more than $0.01 \mathrm{M}$. The reduction was performed four or five times during the entire leaching period of 40 days for pyrite and chalcopyrite, 
while it was done virtually daily (excluding weekends) for sphalerite. The sampling for metal ions was repeated every 3 or 4 days. Also, samples were taken from the anode compartment occasionally and analyzed for total iron and metal ions. The concentration build-up at the anode compartment was attributed to the leakage of solution through the anionic membrane and/or its gaskets.

Metal ions (copper and zinc) were analyzed with an atomic absorption spectrophotometer. These values were used to calculate the leaching conversions of chalcopyrite and sphalerite as a function of time. However, this method was not suitable for determining the leaching conversion of pyrite, because the background ion in the leach solution was soluble iron and the leaching product was also soluble iron. Furthermore, the mass balance on soluble iron was complicated by the precipitation of ferric iron as jarosite. Thus, the leaching conversion of pyrite was only estimated by recovering the unleached pyrite sample at the end of the experiment. The leach slurry was filtered and the solids were dried. Then the dry solids were leached with $200 \mathrm{~mL}$ of $\mathrm{HCl}(2+3)$, a mixture of 40 vol\% of concentrated $\mathrm{HCl}$ and $60 \mathrm{vol} \%$ of deionized water for two hours at room temperature. The slurry was filtered, dried, and the solids were considered to be the unleached pyrite mineral.

Analyses for ferrous and total iron were made by utilizing a titration method that was derived from ASTM D2492-84, which is designed to analyze sulfur forms (pyritic sulfur and sulfate sulfur) from coal. Ferrous ion, after the solution was acidified, was titrated with potassium dichromate using barium diphenylamine as an indicator. The end point was achieved when the color 
changed to violet, and was easily detected. Total iron was analyzed the same way except for pretreatment of the solution. Ferric ion in the solution was reduced to ferrous, using stannous chloride, before titration for total iron with potassium dichromate. Ferric concentration was determined by subtracting ferrous concentration from the total iron concentration.

The precipitation of ferric ion during the leaching of chalcopyrite and sphalerite, probably as jarosite, was calculated as a function of time. The precipitation was calculated by subtracting the total iron available in solution from the total iron that should be available in solution, if there were no precipitation. What is available includes number of moles of soluble total iron in the bioreactor for bioleaching mode, or in the bioreactor, and both the cathode and anode compartments, for the electrobioleaching mode. It also includes the moles of soluble iron removed when samples were taken in both modes of operation. The total iron which should be available, with zero precipitation, is the number of moles of initial total soluble iron (in the solutions) plus those coming from the leaching conversion, particularly for chalcopyrite. However, in the precipitation calculations, the number of moles of iron coming from the possible leaching of impurity minerals (see Table 1) was not considered. This might not cause a significant error in the calculations for sphalerite because the impurity minerals are small in amount (see Table 1). However, in the case of chalcopyrite, the error level may not be trivial because a significant amount of the impurity (pyrite) was present (see Table 1). 


\section{CHAPTER 4 \\ RESULTS AND DISCUSSION}

\subsection{Chalcopyrite Leaching}

Figure 2 compares the leaching conversion of chalcopyrite between the bioleaching and electrobioleaching modes. The two experiments were conducted concurrently for 41 days. It can be seen in Figure 2 that the leaching rates are very low for both methods. The mineral is leached by less than $2 \%$ in 41 days, realizing that it is a reflection of the leaching which has been observed in the past. ${ }^{(8)}$ It can also be seen that despite the small leaching conversions, there is a clear distinction between the two modes of operation. The conversion observed in the electrobioleaching mode is $1.55 \%$ in 41 days, which is more than the conversion in bioleaching mode by $52 \%$. This is a significant improvement.

The improvement can be analyzed using Figures 3 and 4 . Figures 3 and 4 show the variations with time of the concentrations of $\mathrm{Fe}(\mathrm{II}), \mathrm{Fe}(\mathrm{III})$, and total iron for the bioleaching and electrobioleaching modes, respective ly. There seems to be little or no inhibition effect of microbial oxidation of $\mathrm{Fe}(\mathrm{II})$ in the presence of chalcopyrite because Fe(II) ion starts being oxidized right after the initiation of the bioleaching, which can be seen in Figures 3 and 4 . Figure 2 shows that the conversions start deviating from each other at 20 days. This reaction time coincides with when the $\mathrm{Fe}(\mathrm{II})$ concentration dropped to almost zero as can be seen in Figure 3. It is expected that the bacterial activity henceforth is greatly reduced or becomes lukewarm, so that the leaching may 


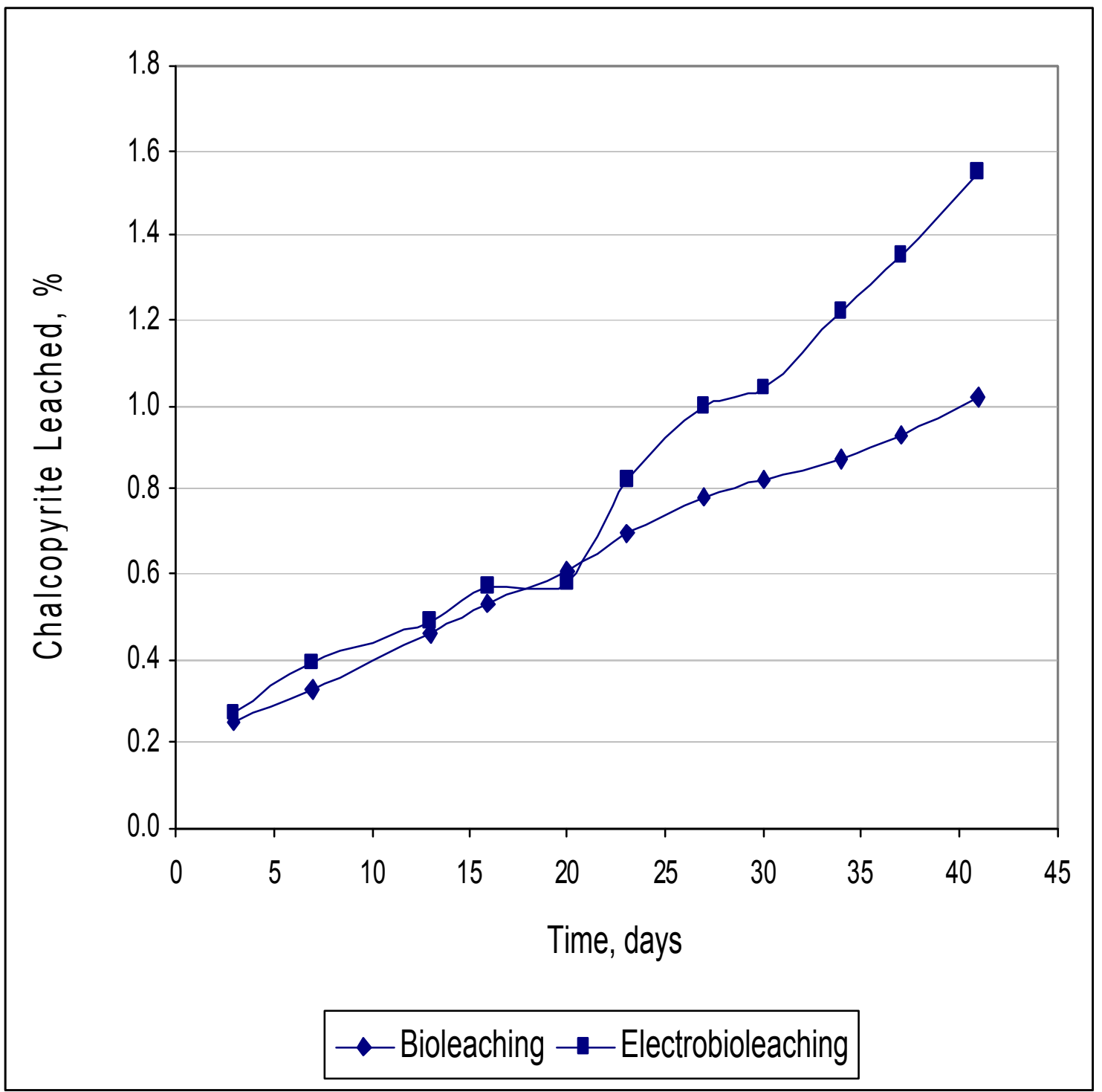

Figure 2. Leaching conversion of chalcopyrite in bioleaching and electrobioleaching modes. 


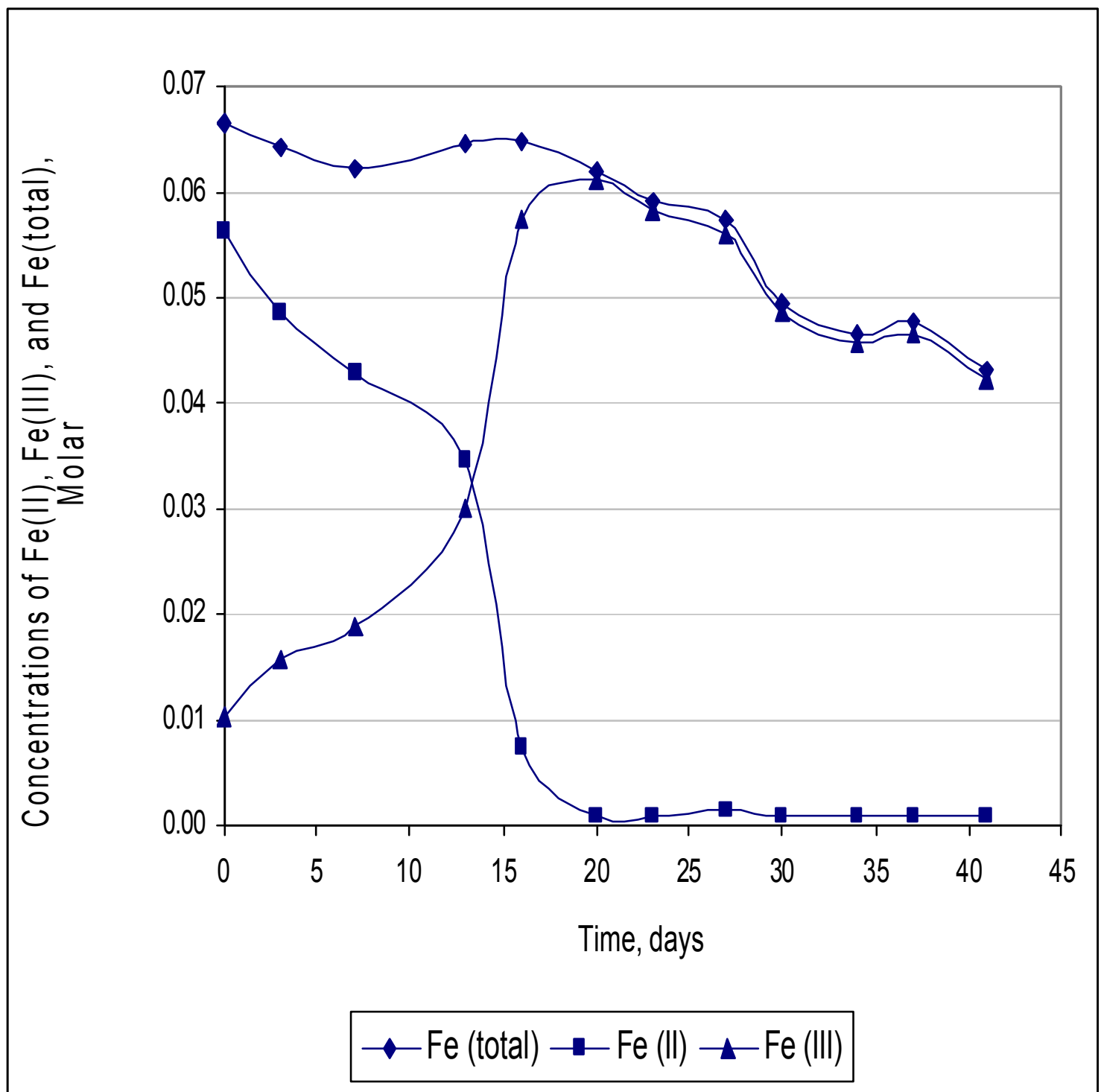

Figure 3. Concentrations of $\mathrm{Fe}(\mathrm{II}), \mathrm{Fe}(\mathrm{III})$, and $\mathrm{Fe}$ (total) during chalcopyrite leaching in bioleaching mode. 


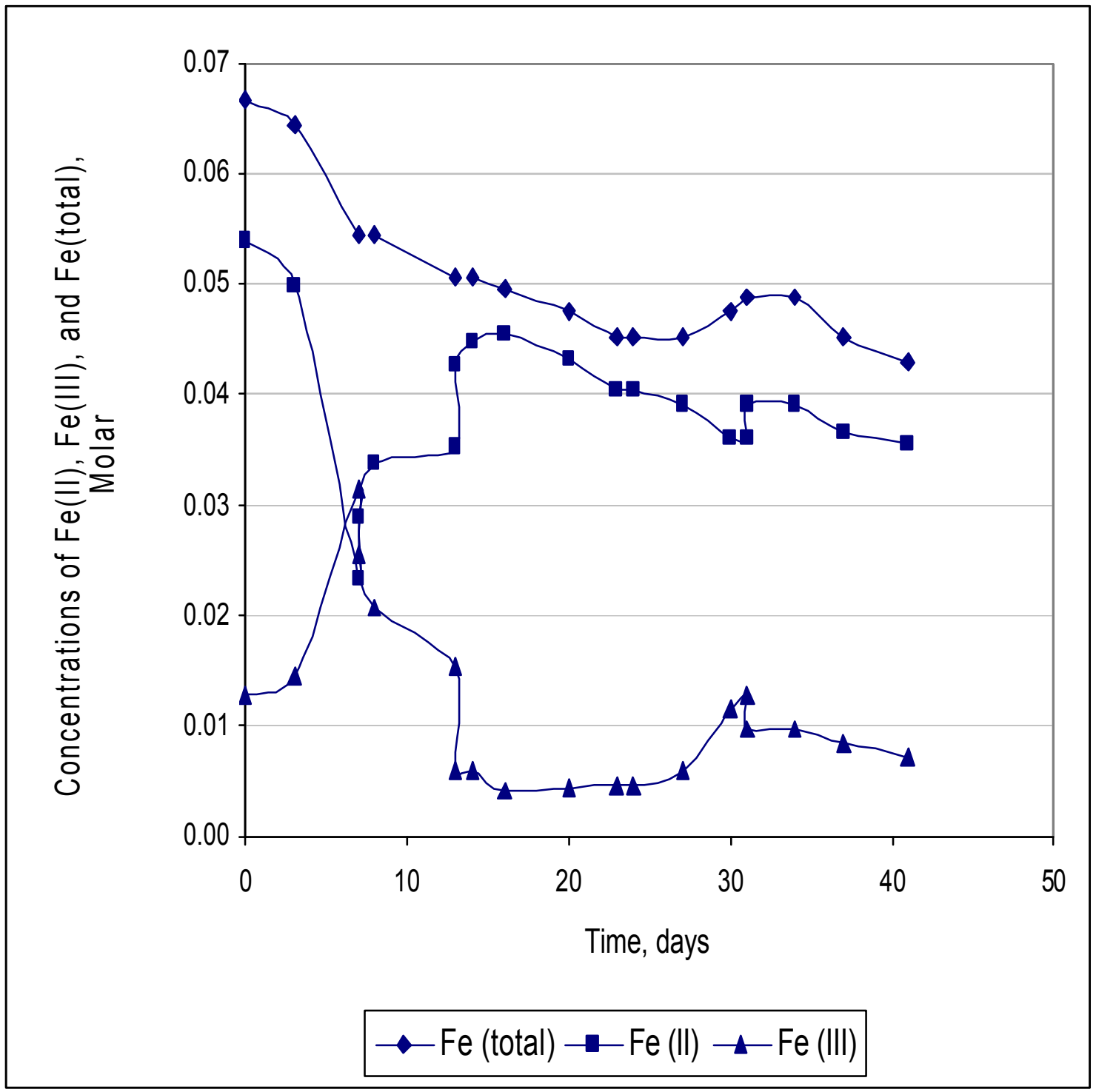

Figure 4. Concentrations of $\mathrm{Fe}(\mathrm{II}), \mathrm{Fe}(\mathrm{III})$, and $\mathrm{Fe}$ (total) during chalcopyrite leaching in electrobioleaching mode. 
take place through oxidation with $\mathrm{Fe}(\mathrm{III})$. In the case of electrobioleaching mode, however, the leaching may take place mostly by the bacterial catalysis because $\mathrm{Fe}$ (II) concentration becomes much higher than in the bioleaching mode, as seen in Figures 3 and 4 . These results, when combined with those shown in Figure 2 suggest that the direct leaching or the microbial catalysis of chalcopyrite takes place faster than the indirect leaching or the leaching with $\mathrm{Fe}(\mathrm{III})$ ion. Compared with the fast rate of the microbial catalysis of chalcopyrite, the bio-oxidation reaction of $\mathrm{Fe}(\mathrm{II})$ (reaction 1) may take place rather slowly. The rate of the reaction (reaction 1) is about 0.0028 mole/day, as can be seen from Figure 3 , which is slow enough to be offset by the electrochemical reduction rate of the electrobioleaching, maintaining a good level of $\mathrm{Fe}(\mathrm{II})$ concentration throughout the leaching reaction (see Figure 4).

The electrochemical reduction of $\mathrm{Fe}(\mathrm{III})$ during the electrobioleaching of chalcopyrite is depicted in Figure 4. The reduction of Fe(III) was made four times with a total electricity of 4840 coulombs. This electricity produced 0.0337 moles of $\mathrm{Fe}(\mathrm{II})$ with a current efficiency of $67.2 \%$. The leakage through the anionic membrane resulted in a $12.2 \%$ loss of soluble iron and a $10 \%$ loss of cupric ion over the 41 day period.

Figure 5 reveals the precipitation of soluble iron during the leaching of chalcopyrite under both the bioleaching and the electrobioleaching modes of operation. There is a marked difference in precipitation between the two modes. The precipitation is $27.3 \%$ in the former mode, while it is only $4.5 \%$ in the latter. This is undoubtedly due to the difference in Fe(III) concentration (see Figures 3 


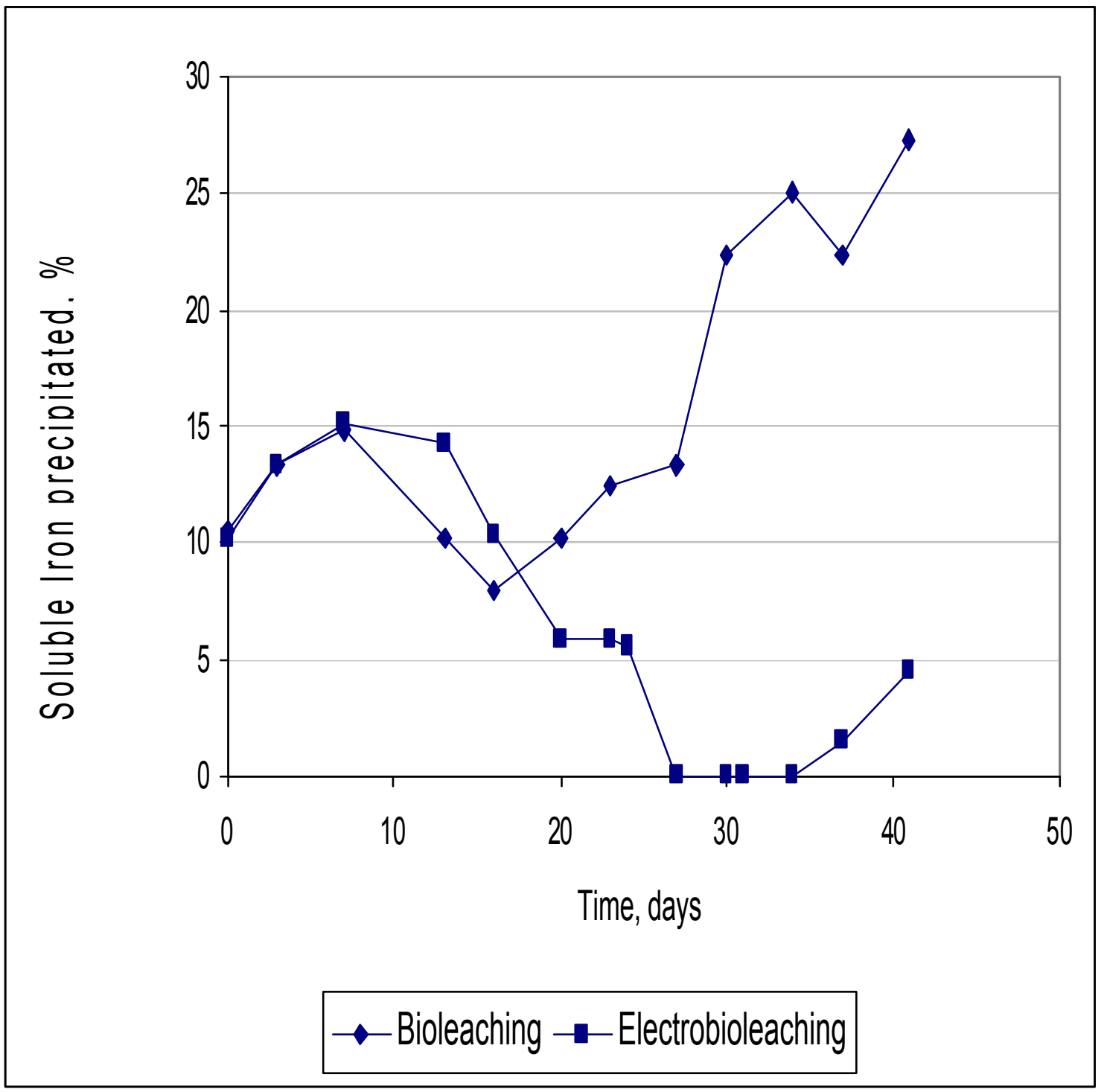

Figure 5. Precipitation of soluble iron during chalcopyrite leaching in bioleaching and electrobioleaching modes. 
and 4). This precipitation may not be influenced by the variation of solution $\mathrm{pH}$. The $\mathrm{pH}$ varied from an initial value of 1.5 to the vicinity of 2 at the end of the experiment for the leaching of all the sulfide minerals throughout this study. $\mathrm{pH}$ variation within this range would not influence the precipitation of jarosite. (10)

$\mathrm{Fe}(\mathrm{III})$ ion would precipitate much more easily than Fe(II). The large difference in iron precipitation between the two modes, as shown in Figure 5, is due to the large difference in $\mathrm{Fe}(\mathrm{III})$ concentration. Large amounts of precipitation in the bioleaching mode depletes $\mathrm{Fe}(\mathrm{III})$ concentration and thus retards the leaching rate. However, this would not happen when operating in electrobioleaching mode if proper electrochemical reduction continues. Thus, a projection is possible; that is, the gap in the leaching conversion between the two modes is likely to be significantly widened as the leaching proceeds. It is concluded then that the electrobioleaching mode of operation is more suitable than the bioleaching mode.

Two experiments were conducted to leach chalcopyrite and sphalerite with only Fe(III) ion. The experiments were conducted in the bioreactor with a $20 \mathrm{~g}$ mineral sample in a 1 -liter solution of 0.053 molar Fe(III). No bacteria culture was used in the solution. The results are shown in Figure 6. One can see that the leaching rate of chalcopyrite with $\mathrm{Fe}(\mathrm{III})$ is slightly lower than that observed in Figure 2, especially in the early stage (less than 7 days), which might result from both direct and indirect leaching mechanisms.

The contributing factors of the direct and indirect leaching rates may be estimated as follows: The leaching of chalcopyrite with ferric sulfate follows the 


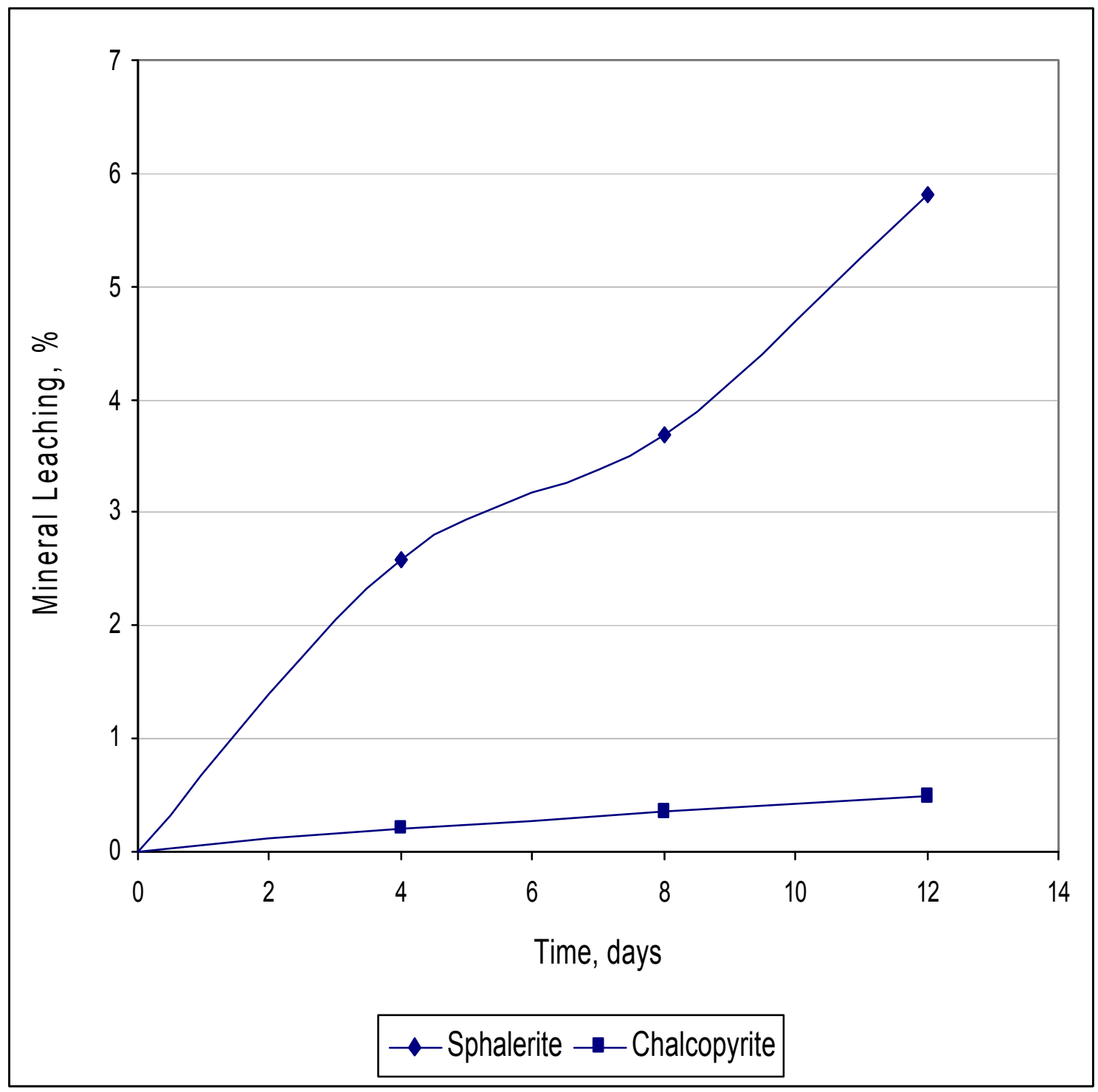

Figure 6. Leaching of chalcopyrite and sphalenite in $0.053 \mathrm{M}$ ferric solution. 
diffusion model through the product layer of elemental sulfur. ${ }^{\left({ }^{8}\right)}$ The rate equation is given by ${ }^{(11)}$

$1-\frac{2}{3} x-(1-x)^{2 / 3}=\frac{2 k V c}{r_{o}^{2} \sigma} t$

where: $\quad x=$ leaching conversion

$\mathrm{c}=$ concentration of $\mathrm{Fe}(\mathrm{III})$ (mole/liter)

$\mathrm{k}=$ rate constant $\left(\mathrm{cm}^{2} /\right.$ days $)$

$V=$ chalcopyrite molar volume (liter/mole)

$\sigma=$ stoichiometric factor, 4 in this case (see reaction 4 )

$r_{0}=$ average radius of chalcopyrite particle $(\mathrm{cm})$

$t=$ reaction time (day)

Equation 9 can be rewritten as

$1-\frac{2}{3} x-(1-x)^{2 / 3}=k K c$

where, $\quad K=\frac{2 V t}{r_{o}^{2} \sigma}$

The leaching conversion is $0.38 \%$ at $0.053 \mathrm{M}$ and at 12 days as shown in Figure 6. Then $k_{1} K c=1.609 \times 10^{-6}$ and $k_{1} K=3.04 \times 10^{-5} \frac{\text { liter }}{\text { mole }}$ where $\mathrm{k}_{1}$ is the rate constant for the indirect reaction. The leaching conversion under the combined mechanisms is $0.428 \%$ at the average concentration of $\mathrm{Fe}(\mathrm{III}), 0.0189 \mathrm{M}$ and 12 days as shown in Figures 2 and 3 for the bioleaching mode. Then, $\left(k_{1}+k_{2}\right) K c$ is 
$2.036 \times 10^{-6}$ and $\left(k_{1}+k_{2}\right) K=1.077 \times 10^{-4} \frac{\text { liter }}{\text { mole }}$ where $\mathrm{k}_{2}$ is the rate constant of the direct reaction. Since $\mathrm{K}$ is the same in both cases, it can be determined that $\mathrm{k}_{2}=$ $2.52 k_{1}$. The estimation is that the rate constant of direct leaching by microbial catalysis, in the early stages, is 2.52 times as high as that of indirect leaching. This is in good agreement with the leaching mechanisms mentioned previously.

\subsection{Sphalerite Leaching}

Figure 7 shows the leaching conversion of sphalerite in the bioleaching and electrobioleaching modes. It is observed that the leaching conversion in electrobioleaching mode is slightly higher than in bioleaching mode during the initial stage (up to 15 days), significantly higher in the middle stage (15 to 40 days), and then becomes virtually the same in the final stage (beyond 40 days). This comparison may be analyzed using the data as given in Figures 8 and 9 , which show how the concentrations of soluble iron forms vary with time.

It is seen in Figure 8 that the $\mathrm{Fe}(\mathrm{II})$ concentration is maintained at a plateau-like state before dropping to virtually nil. This type of inhibition is believed to be rare and the behavior is not well understood at this moment. The plateau portion, up to 28 days, may be considered as an incubation period where the population or the catalysis of the bacteria is not large enough to oxidize Fe(II) (reaction 1). Then the cascading portion, after 28 days, is the breaking point of the incubation. 


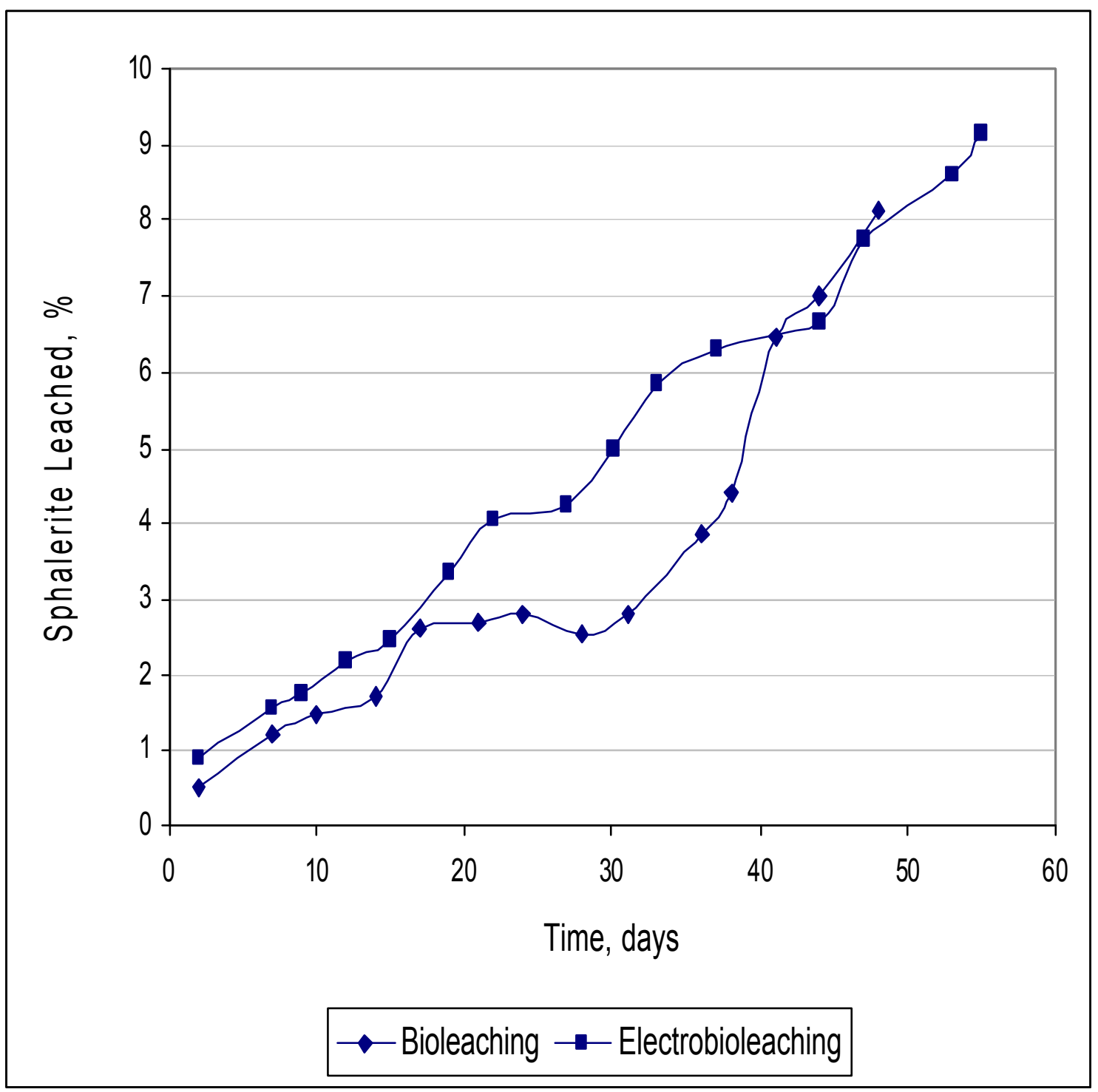

Figure 7. Leaching conversion of sphalerite in bioleaching and electrobioleaching modes. 


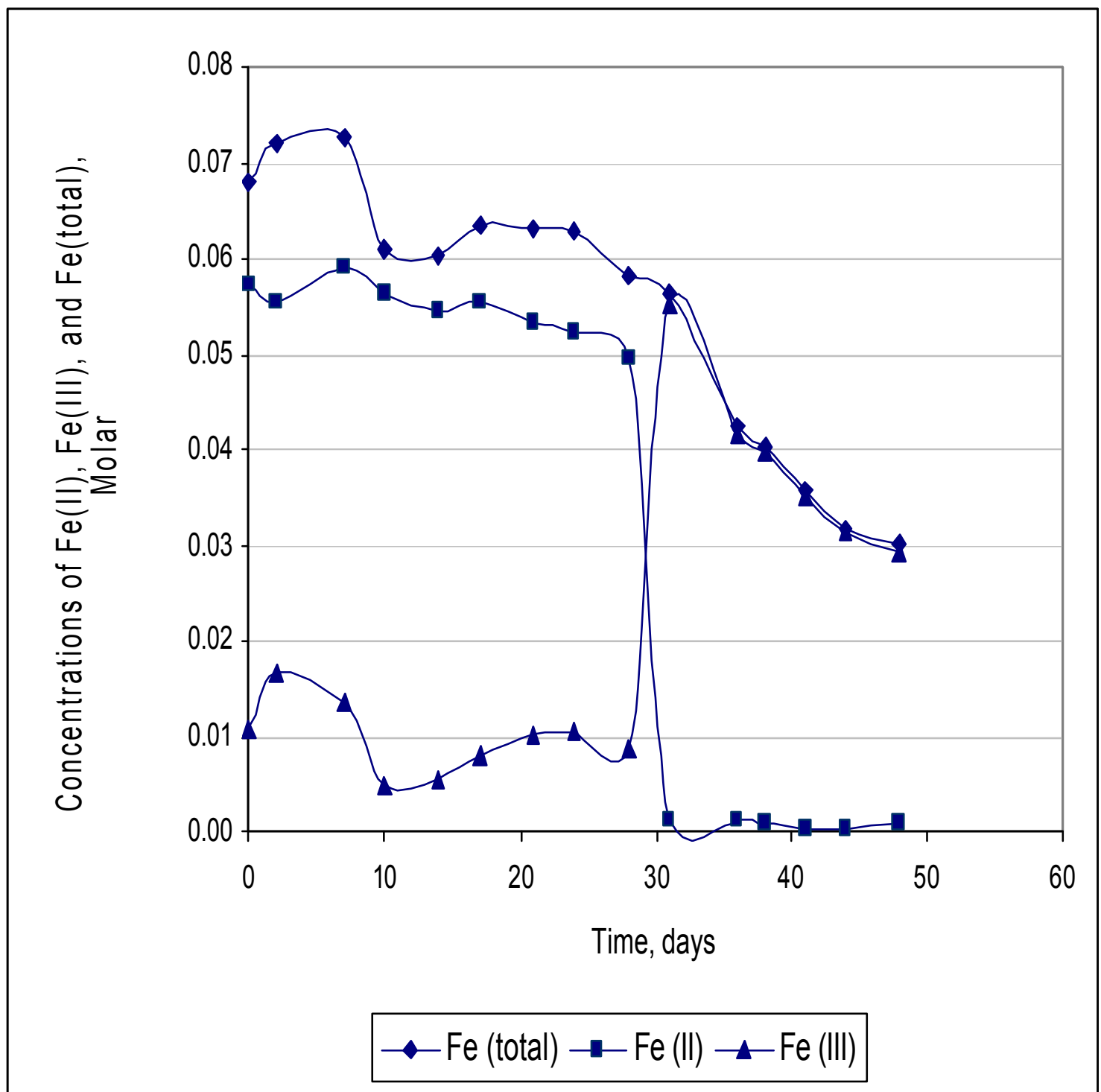

Figure 8. Concentrations of $\mathrm{Fe}(\mathrm{II}), \mathrm{Fe}(\mathrm{III})$, and Fe(total) during sphalerite leaching in bioleaching mode. 


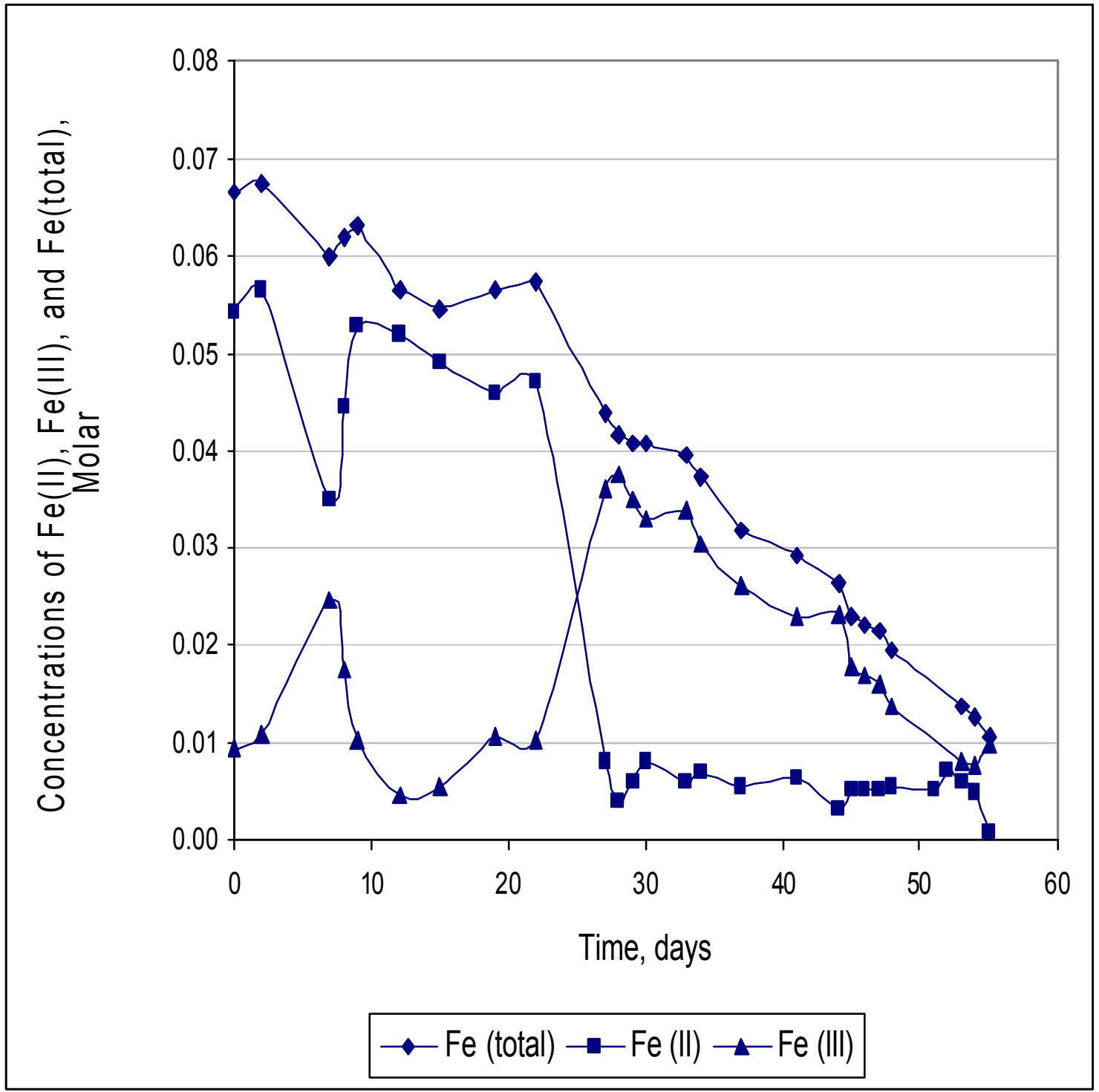

Figure 9. Concentrations of $\mathrm{Fe}(\mathrm{II}), \mathrm{Fe}(\mathrm{III})$, and $\mathrm{Fe}($ total) during sphalerite leaching in electrobioleaching mode. 
It is considered that an extra contribution is made besides the sustained $\mathrm{Fe}(\mathrm{II})$ in breaking the incubation. It must be another bioreaction, or the sulfur oxidation reaction (reaction 2) that energizes the growth of the bacteria. The elemental sulfur is produced by the leaching of the mineral with Fe(III) (reaction 5). Since the leaching conversion of sphalerite reaches $2.8 \%$ after 28 days, the elemental sulfur produced amounts to 0.005 mole. This elemental sulfur might help to break the incubation. Another crucial aspect of Figure 8 is that the oxidation rate of $\mathrm{Fe}(\mathrm{II})$ is 0.016 mole/day, which is 5.7 times faster than that for chalcopyrite. Thus, after the collapse of incubation, all the soluble iron exists as Fe(III) because the disappearance rate of $\mathrm{Fe}(\mathrm{II})$ (reaction 1) is faster than the production rate of $\mathrm{Fe}(\mathrm{II})$ (reaction 5).

The incubation portion is also visible in Figure 9 in the case of the electrobioleaching mode. A dip, at 7 days, of $\mathrm{Fe}(\mathrm{II})$ is not due to microbial oxidation of $\mathrm{Fe}(\mathrm{II})$. It is rather because the solution was diluted with the catholyte. It is seen in Figure 9 that the collapse of incubation occurs between 22 and 27 days. This is earlier than what is observed in bioleaching mode. During the period up to 22 days, an amount of electricity is used to produce 0.029 molar of $\mathrm{Fe}(\mathrm{II})$ concentration. This electrical production of $\mathrm{Fe}(\mathrm{II})$ must help to shorten the incubation period from 28 to 22 days. As can be seen in Figure 9, the oxidation rate of $\mathrm{Fe}(\mathrm{II})$ at the incubation breaking point is $0.0156 \mathrm{~mole} / \mathrm{day}$ which is virtually the same as that for bioleaching mode, and is 5.6 times larger than that for leaching chalcopyrite in electrobioleaching mode. 
This fast rate maintains a predominant concentration level of $\mathrm{Fe}(\mathrm{III})$, as seen in Figure 9, between 30 and 55 days, despite the continuous production of $\mathrm{Fe}(\mathrm{II})$ electrochemically, suggesting that the bio-oxidation rate of $\mathrm{Fe}(\mathrm{II})$ (reaction 1 ) is much higher than that of reaction 5.

The higher leaching conversion with the electrobioleaching mode in the middle stage, as shown in Figure 7, may be due to the fact that the combined effect of $\mathrm{Fe}(\mathrm{III})$ and microbial catalysis is larger than that for the bioleaching mode. The equality of the leaching conversion in the final stage may also be due to the equality of the combined effect of $\mathrm{Fe}(\mathrm{III})$ and microbial catalysis. The overall picture is that the leaching conversion did not improve much while the system was strenuously promoted by producing much $\mathrm{Fe}(\mathrm{II})$ ions in the electrobioleaching mode. This suggests that the indirect leaching reaction (reaction 5) takes place faster than the microbial catalysis reaction (reaction 8). This finding is reflected in the literature. ${ }^{(5)}$

The precipitation of soluble iron during the leaching reactions in the two modes of operation is shown in Figure 10. One can see from this figure that the precipitation is almost the same for the bioleaching and electrobioleaching modes. This may be because the time-average concentrations of $\mathrm{Fe}(\mathrm{III})$ are almost at the same level throughout the leaching. One important observation from Figure 10 is that the precipitation reaches almost $60 \%$ in 55 days at the leaching conversion of only $8.2 \%$. 


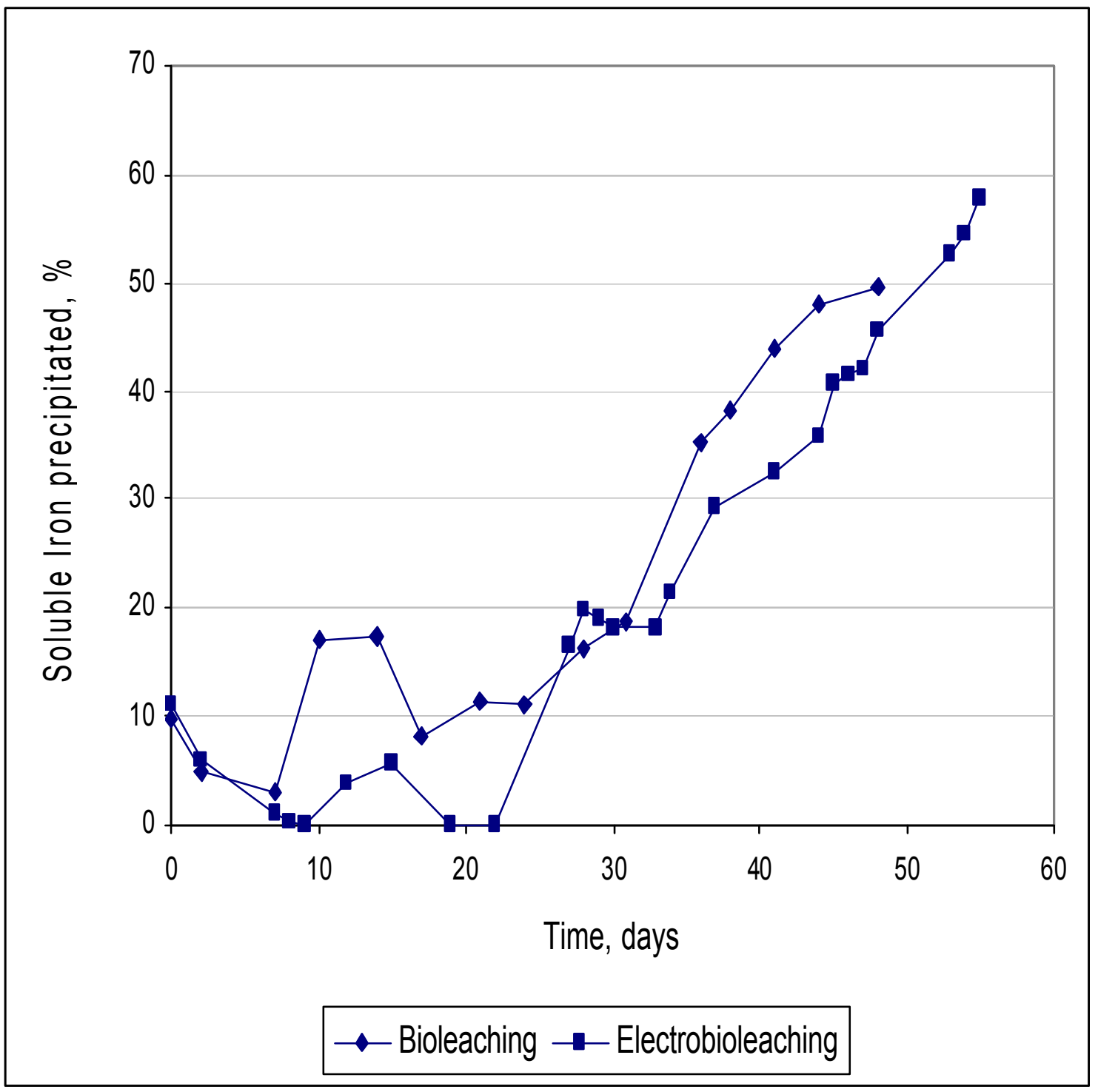

Figure 10. Precipitation of soluble iron during sphalerite leaching in bioleaching and electrobioleaching modes. 
This large loss of reagent may result from the mechanism in which once the incubation effect of the $\mathrm{Fe}(\mathrm{II})$ oxidation collapses, the oxidation of $\mathrm{Fe}(\mathrm{II})$ is accelerated by the microbial catalysis, and, as such, the produced $\mathrm{Fe}(\mathrm{III})$ is subject to precipitation. In the case of electrobioleaching mode, the situation is not much different. $\mathrm{Fe}(\mathrm{III})$ was reduced daily to $\mathrm{Fe}(\mathrm{II})$. However, once the incubation effect of the $\mathrm{Fe}(\mathrm{II})$ oxidation collapses, the microbial oxidation rate of converting $\mathrm{Fe}(\mathrm{II})$ to $\mathrm{Fe}(\mathrm{III})$ is overwhelmingly higher than the combined rate of electrochemical reduction and indirect leaching (reaction 5). This situation maintains the $\mathrm{Fe}(\mathrm{III})$ concentration in predominance which, in turn, causes the massive precipitation of the ferric ion. It is concluded then that the electrobioleaching mode is not better than the bioleaching mode. Furthermore, the bioleaching of sphalerite does not have salient advantages over chemical leaching with $\mathrm{Fe}(\mathrm{III})$ because iron precipitation would be smaller while achieving as much leaching conversion in the latter method.

The electrochemical reduction of $\mathrm{Fe}(\mathrm{III})$ to $\mathrm{Fe}(\mathrm{II})$ was conducted and the results are shown in Figure 9. The concentrations are the ones measured right after the electrochemical reduction took place. The reduction of $\mathrm{Fe}(\mathrm{III})$ was made using a total electricity of 20103 coulombs. This electricity produced 0.168 moles of $\mathrm{Fe}(\mathrm{II})$ from which the current efficiency was found to be $80.4 \%$. This electricity is 4.2 times as much as was used in the electrobioleaching of chalcopyrite. As yet, the effect of microbial catalysis is lower than that of chalcopyrite leaching, as indicated by the differentials in leaching conversion between the two modes of operation (see Figures 2 and 7). The leakage of ions through the anionic 
membrane and/or rubber gaskets was determined. Over the 55-day period, the loss of soluble iron was $13.5 \%$ and the loss of zinc ion was $9.6 \%$. This is similar to what was observed in the chalcopyrite leaching experiments.

The contribution made by each leaching mechanism (indirect and direct) in the early stages can be estimated using the data in Figures 6 and 7 . The leaching conversion was $5.8 \%$ with 0.053 molar $\mathrm{Fe}$ (III) at 12 days, as shown in Figure 6 , while it was $1.61 \%$ with 0.01 molar $\mathrm{Fe}(\mathrm{III})$ at 12 days, as shown in Figure 7 . The former represents the indirect leaching mechanism and the latter represents the combination of the indirect and direct leaching mechanisms. The leaching of sphalerite with ferric sulfate follows the shrinking core model in the early stages. ${ }^{(9)}$ The equation for the shrinking core model can be written as ${ }^{(12,}$ 13)

$$
1-(1-x)^{1 / 3}=\frac{k^{\prime} V c}{r_{o}} t
$$

where: $\quad x=$ leaching conversion

$$
\begin{aligned}
& c=\text { concentration of } \mathrm{Fe}(\mathrm{III})(\text { mole/liter }) \\
& \mathrm{k}^{\prime}=\text { rate constant }(\mathrm{cm} / \mathrm{day}) \\
& \mathrm{V}=\text { chalcopyrite molar volume }(\text { liter/mole }) \\
& r_{0}=\text { average radius of chalcopyrite particle }(\mathrm{cm}) \\
& \mathrm{t}=\text { reaction time }(\text { day })
\end{aligned}
$$

Equation 11 can be rewritten as

$1-(1-x)^{1 / 3}=k^{\prime} K^{\prime} c$ 
where $K^{\prime}=\frac{V t}{r_{o}}$ and is the same for the two cases. By substituting the values previously mentioned into Equation $12, \mathrm{k}_{1}{ }^{\prime} \mathrm{K}^{\prime}$ was found to be 0.372 liter/mole where $k_{1}{ }^{\prime}$ is the rate constant for the indirect reaction (reaction 5). Also, $\left(\mathrm{k}_{1}{ }^{\prime}+\mathrm{k}_{2}{ }^{\prime}\right) \mathrm{K}^{\prime}$ was found to be 0.539 liter/mole where $\mathrm{k}_{2}$ ' is the rate constant for direct reaction (reaction 8). Further calculations show that $\mathrm{k}_{2}^{\prime}=0.45 \mathrm{k}_{1}$ '. This is in meaningful contrast with that for chalcopyrite leaching. The rate constant of the bioleaching reaction of chalcopyrite (reaction 7 ) is more than twice than that of the rate constant of the chemical reaction (reaction 4). However, in the case of sphalerite, it is only $45 \%$ of the chemical reaction rate constant. This inequality of reaction rates has been delineated previously in this subsection.

\subsection{Pyrite Leaching}

As mentioned previously, the leaching conversion of pyrite could not be determined. However, the values with the two modes were estimated by recovering unleached pyrite samples at the end of the experiments. The values were $11.5 \%$ for electrobioleaching mode and $8.1 \%$ for bioleaching mode. The ratio of the two is 1.42 , which is somewhat smaller than what was found in the case of chalcopyrite leaching (1.52).

Figures 11 and 12 show the concentration variations with time of $\mathrm{Fe}(\mathrm{II})$, $\mathrm{Fe}(\mathrm{III})$ and $\mathrm{Fe}$ (total) during the leaching reactions using both bioleaching and electrobioleaching modes, respectively. 


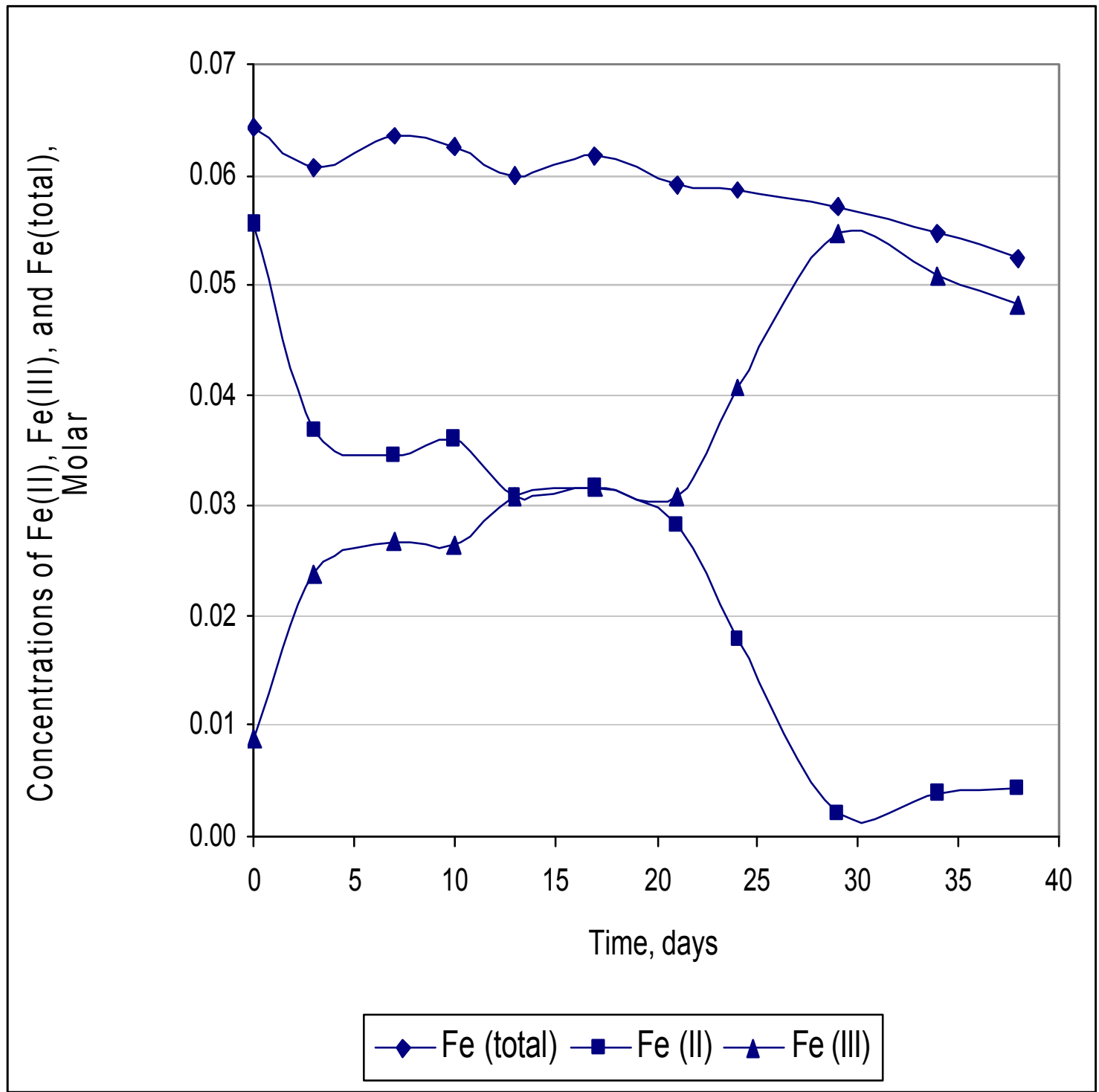

Figure 11. Concentrations of $\mathrm{Fe}(\mathrm{II}), \mathrm{Fe}(\mathrm{III})$, and $\mathrm{Fe}($ total) during pyrite leaching in bioleaching mode. 


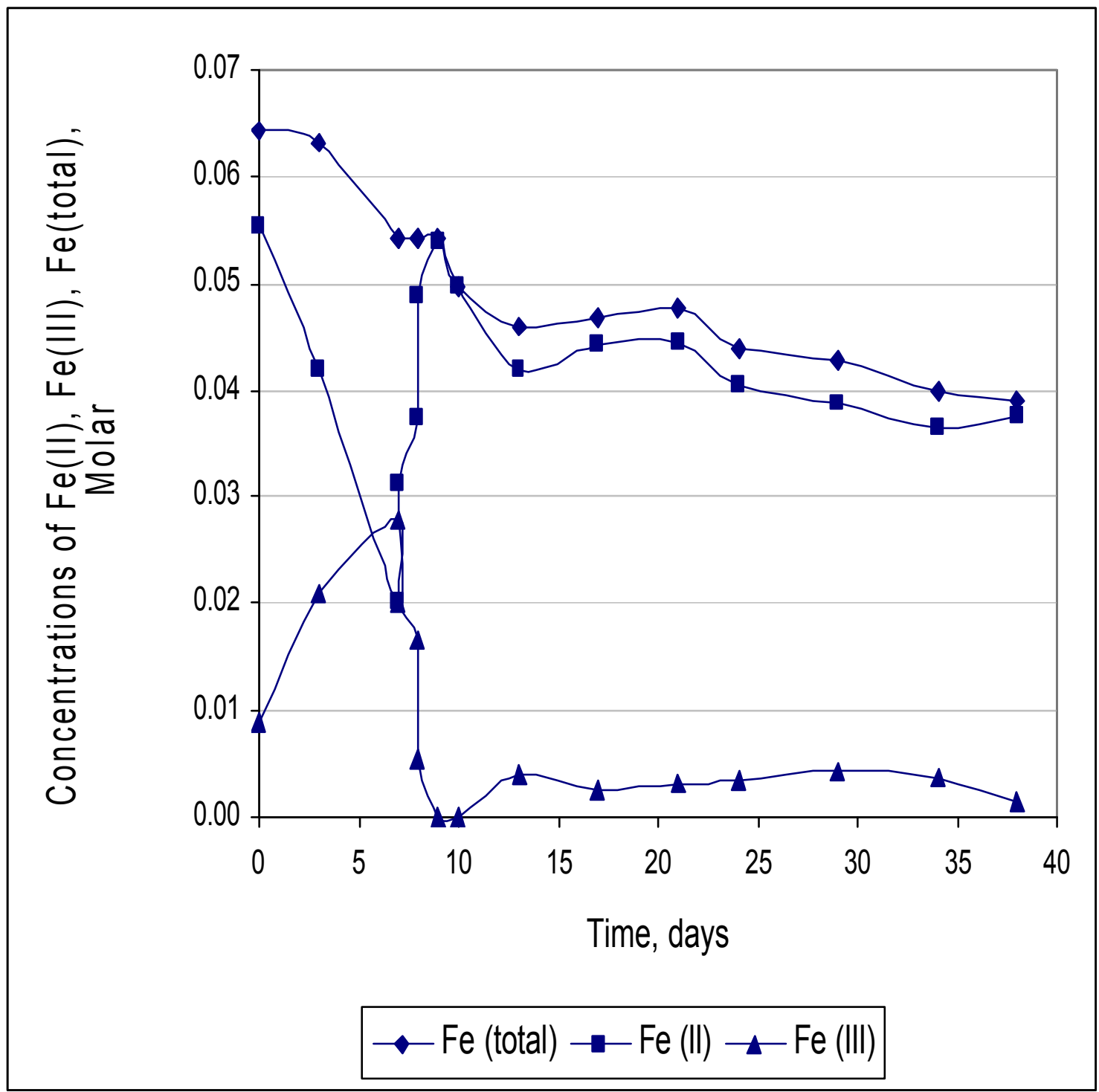

Figure 12. Concentrations of $\mathrm{Fe}(\mathrm{II}), \mathrm{Fe}(\mathrm{III})$, and $\mathrm{Fe}$ (total) during pyrite leaching in electrobioleaching mode. 
Comparisons among Figures 3, 8, and 11 can distinguish the patterns with which $\mathrm{Fe}(\mathrm{II})$ concentration varies with time for the leaching of the three minerals. As can be seen in Figure 11, Fe(II) concentration drops initially and then is maintained at approximately the same level for 14 days, before dropping to small values. The plateaullike region may be due to the incubation effect of $\mathrm{Fe}(\mathrm{II})$ oxidation in the presence of pyrite. It can be seen that this effect with pyrite somewhat resembles that of sphalerite.

Comparison among Figures 4, 9, and 12 distinguishes the patterns with which $\mathrm{Fe}(\mathrm{II})$ concentration varies with time for the leaching of the three minerals in electrobioleaching mode. It can be seen, in Figure 12, that the incubation effect seen in Figure 11, is eliminated by the electrochemical reduction of $\mathrm{Fe}(\mathrm{III})$. It can also be seen that the pattern for pyrite, as shown in Figure 12, is almost identical to that of chalcopyrite (see Figure 4). This suggests that the leaching mechanisms of pyrite are based on those of chalcopyrite, especially in terms of the relationship between the leaching rates of the direct and indirect reactions, as well as the relationship between $\mathrm{Fe}(\mathrm{II})$ production and disappearance (reactions 3 and 1). This also suggests that the electrobioleaching of pyrite is viable for wider applications. The reduction was made three times for the entire period using 6241 coulombs to reduce 0.0526 moles of $\mathrm{Fe}(\mathrm{III})$ with a current efficiency of $81.3 \%$. 


\section{CHAPTER 5 \\ CONCLUSIONS}

The electrobioleaching of chalcopyrite has advantages over the bioleaching of the mineral with respect to the fact that the leaching conversion is higher by $52 \%$, while the total soluble iron precipitation is much lower, $4.5 \%$ versus $27.3 \%$. The bioleaching rate is predominantly higher than the chemical leaching rate using only $\mathrm{Fe}(\mathrm{III})$. In addition to this, high levels of $\mathrm{Fe}(\mathrm{II})$ can be maintained by electrochemical reduction of $\mathrm{Fe}(\mathrm{III})$ which in turn minimizes the iron precipitation, and helps to grow the bacteria.

Nearly the opposite phenomena are observed for the electrobioleaching of sphalerite. This method of leaching is not an improvement over the bioleaching method. The microbial oxidation rate of $\mathrm{Fe}(\mathrm{II})$ to $\mathrm{Fe}(\mathrm{III})$ is much higher than the chemical leaching rate with $\mathrm{Fe}(\mathrm{III})$, which produces $\mathrm{Fe}(\mathrm{II})$. This mechanism tends to maintain a predominant level of $\mathrm{Fe}(\mathrm{III})$ concentration, which results in massive precipitation of iron, which in turn incapacitates the electrochemical reduction of $\mathrm{Fe}(\mathrm{III})$ to $\mathrm{Fe}(\mathrm{II})$.

The effect of electrobioleaching on pyrite is similar to that of chalcopyrite. The electrochemical reduction of $\mathrm{Fe}(\mathrm{III})$ to $\mathrm{Fe}(\mathrm{II})$ is pronounced and maintains a predominant level of $\mathrm{Fe}(\mathrm{II})$ concentration, which is the basis for accelerating the bioleaching of pyrite. The application of this electrobioleaching method on pyrite could be extended to applications like coal desulfurization and pretreatment of Carlin-type gold ore (refractory gold ore) in heap leaching. 


\section{BIBLIOGRAPHY}

(1) M.E. Wadsworth, in Proceedings of $23^{\text {rd }}$ Annual Conference of Metallurgists of Canadian Institute of Mining and Metallurgy, 1984, p.1.

(2) K.A. Natarajan, "Electrobioleaching of Base Metal Sulfides," Metallurgical Transactions B, February 1992, pp. 5-11.

(3) S.B. Yunker and J.M. Radovich, "Enhancement of Growth and Ferrous Iron Oxidation Rates of $T$. ferrooxidans by Electrochemical Reduction of Ferric Iron," Biotechnology and Bioengineering, 1986, vol. 28, pp. 18671875.

(4) Satoshi Nakasono, Norio Matsumoto and Hiroshi Saiki, "Electrochemical Cultivation of Thiobacillus ferrooxidans by Potential Control," Bioelectrochemistry and Bioenergetics, 1997, vol. 43, pp. 61-66.

(5) M. Boon and J.J. Heijinen, "Mechanisms and Rate Limiting Steps in Bioleaching of Sphalerite, Chalcopyrite and Pyrite with Thiobacillus ferrooxidans," in Proceedings of an International Biohydrometallurgy Symposium, Jackson Hole, Wyoming, August 22-25, 1993, Biohydrometallurgical Technologies vol. 1 - Bioleaching Process, edited by A.E. Torma, J.E. Wey, and V.I. Laksmanan, a publication of TMS, pp. 217-235.

(6) A. Malik, M.G. Dastidar, and P.K. Roychoudhury, "Factors limiting Bacterial Iron Oxidation in Biodesulphurization System," International Journal of Mineral Processing, 2004, vol. 73, pp. 13-21.

(7) A.E. Torma, C.C. Walden, and R.M.R. Branian, "Microbiological Leaching of Zinc Sulphide Concentrate," Biotechnology and Bioengineering, 1970, vol. 12, pp. 501-517.

(8) P.B. Munoz, J.D. Miller, and M.E. Wadsworth, "Reaction Mechanism for the Acid Ferric Sulfate Leaching of Chalcopyrite," Metallurgical Transactions B, June 1979, vol. 10B, pp. 149-158.

(9) J. Lochmann and M. Pedlik, "Kinetic Anomalies of Dissolution of Sphalerite in Ferric Sulfate Solution," Hydrometallurgy, 1995, vol. 37, pp. 89-96.

(10) J. E. Dutrizac, "Factors Affecting Alkali Jarosite Precipitation," Metallurgical Transactions B, December 1983, vol. 14B, pp. 531-539. 
(11) Fathi Habashi, "Principles of Extractive Metallurgy," vol. 1, p. 158, Science Publishers, New York, 1970.

(12) Zuo-Mei Jin, G. W. Warren, and H. Henein, "Reaction Kinetics of the Ferric Chloride Leaching of Sphalerite - An Experimental Study," Metallurgical Transactions B, March 1984, vol. 15B, pp. 5-12.

(13) Eung Ha Cho, "Kinetics of Sodium Carbonate Leaching of Scheelite," Journal of Metals, July 1988, vol. 40, no. 7, pp. 32-34. 